\title{
Veřejný zájem a transparentnost v mezinárodní obchodní arbitráži
}

\author{
Public Interest and Transparency \\ in International Commercial Arbitration
}

\author{
Klára Drličková*
}

\begin{abstract}
Abstrakt
Cílem tohoto clánku je analýza otáaky transparentnosti v mezinárodni obchodni arbitráži. Článek sméruje zejména k zodpovězeni otázky, zda existuje verejný zájem na systematickém zveřjñováni rozhodüich nálezü. V úvodu je stručně shrnut současný stav neverejnosti a divèrrnosti v mezinárodni obchodni arbitrá-

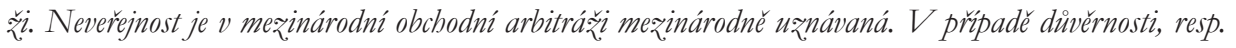
mlčenlivosti v současné dobè jednotná koncepce neexistuje. Problematická je zejména existence povinnosti stran zachovat mlčenlivost. Její existence, rozsah a výjimky z. ni se mohou lišit stát od státu. K prolomení

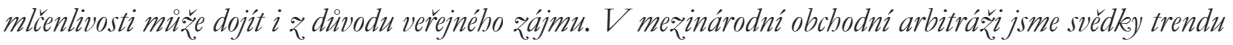
smèrem ke vyšš míre transparentnosti. Nelze ovšem uvažovat o siroce koncipované transparentnosti ve smy-

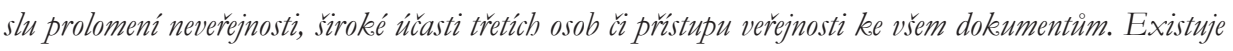

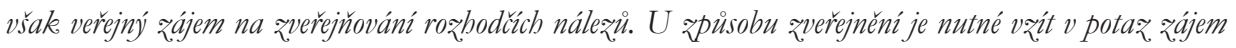
stran na zachováni divvérnosti roz̧̧oď̌ího nálezu.
\end{abstract}

\section{Klíčová slova}

Mezinárodni obchodni arbitrá̌̌; neverejenost; di̛věrnost; mľ̌enlivost; verejný zájem; transparentnost; rozbodři nález:

\section{Abstract}

The aim of this article is to analyse the issue of transparency in international commercial arbitration. In particular, the article aims to answer the question whether there is a public interest in the systematic publication of arbitral awards. First, the current state of privacy and confidentiality in international commercial arbitration is briefly summarized. Privacy of international commercial arbitration is not disputed. In the case of confidentiality, there is no universally accepted solution. Especially, the duty of the parties to maintain confidentiality is problematic. Its existence, scope and limits differ from state to state. Public interest is one of the possible limits of confidentiality. We are witnessing a trend towards a greater transparency in international commercial arbitration. The transparency cannot be construed in a broad sense. The privacy should be respected, the public should not have access to hearings and to all documents produced in arbitration. However, there is a public interest in the publication of awards. Considering the way of publication, the interest of the parties in maintaining confidentiality of arbitral awards must be taken into account.

\section{Keywords}

International Commercial Arbitration; Privacy; Confidentiality; Public Interest; Transparency; Arbitral Award.

* JUDr. Klára Drličková, Ph.D., Katedra mezinárodního a evropského práva, Právnická fakulta, Masarykova univerzita, Brno / Department of International and European Law, Faculty of Law, Masaryk University, Brno, Czech Republic / E-mail: klara.drlickova@email.cz / ORCID: 0000-0002-5644-1441 


\section{1 Úvod $^{1}$}

Mezinárodní obchodní arbitráž² (dále také i „rozhodčí řízeni") je v současné době převažujícím způsobem řešení obchodních sporů s mezinárodním prvkem. Zároveň se rozšiřuje i okruh sporů, které mohou být v mezinárodním rozhodčím řízení řešeny. Moderní úpravy rozhodčího řízení tíhnou k rozšiřování tzv. objektivní arbitrability. ${ }^{3} \mathrm{~V}$ rozhodčím řízení tak nejsou řešeny pouze spory, které se dotýkají výlučně zájmů sporných stran. Jsou řešeny i spory vznikající z ekonomických aktivit, které se dotýkají zájmů veřejných. ${ }^{4}$ Jedná se o např. o soukromoprávní vynucování pravidel hospodářské soutěže, spory dotčené nezákonným jednáním, spory z práv duševního vlastnictví (v některých státech i s účinky erga omnes), spory dotčené insolvenčním řízením atd. Stranou mezinárodní obchodní arbitráže může být i stát.

Mezinárodní obchodní arbitráž je tradičně vnímána jako neveřejný a důvěrný způsob řešení sporů. Neveřejnost a důvěrnost/mlčenlivost jsou rovněž uváděny mezi výhodami rozhodčího ř́zení a jako jeden z hlavních důvodů, proč strany upřednostňují arbitráž před řešením sporů před národními soudy. ${ }^{5}$ Neveřejnost rozhodčího řízení a povinnost zachovat mlčenlivost jsou především v zájmu stran rozhodčího řízení. Pokud by byly absolutní, třetí osoby by se nemohli řízení zúčastnit a nemohla by jím být vyzrazena

1 Článek vznikl v rámci řešení projektu financovaného GAČR - GA15-08182S Role veřejného zájmu v mezinárodní obchodní a investiční arbitráži.

2 V oblasti mezinárodní obchodní arbitráže existuje významný podíl mezinárodní úpravy, která má vliv na formování právní úpravy na národní úrovni. Existují i další výrazné snahy směrující ke sjednocení právní úpravy tohoto institutu. Přesto je právní úprava mezinárodní obchodní arbitráže stále doménou národního práva. I samotné vymezení mezinárodní obchodní arbitráže se tak může v jednotlivých státech lišit. Pro účely tohoto článku mezinárodní obchodní arbitráží rozumíme způsob řešení obchodních sporů s mezinárodním prvkem. Mezinárodní obchodní arbitráží není arbitráž mezi státy, arbitráž investiční, arbitráž sportovní, arbitráž spotřebitelská a arbitráž mezi soukromými osobami, jejichž poměr nelze kvalifikovat jako obchodní.

3 Pro účely tohoto článku je arbitrabilita vnímána $\mathrm{v}$ jejím nejrozšíŕenějším smyslu, a to jako přípustnost řešení sporu v rozhodčím řízení. Tedy jinými slovy, vymezení okruhu sporů, které jsou právním řádem připuštěny $\mathrm{k}$ řešení $\mathrm{v}$ rozhodčím řízení.

4 Veřejným zájmem pro účely tohoto článku autorka rozumí zájem širšího okruhu osob, než jsou strany konkrétního rozhodčího řízení.

5 BLACKABY, Nigel, Constantine PARTASIDES, Alan REDFERN a Martin HUNTER. Redfern and Hunter on International Arbitration. 6th ed. New York: Oxford University Press, 2015, s. 30; NOUSSIA, Kyriaki. Confidentiality in International Commercial Arbitration. Berlin - Heidelberg: Springer - Verlag, 2010, s. 1; BUYS, Cindy G. The Tension between Confidentiality and Transparency in International Arbitration. The American Review of International Arbitration. 2003, roč. 14, s. 121; viz i 2015 International Arbitration Survey: Improvements and Innovations in International Arbitration [online]. White \& Case, School of International Arbitration Queen Mary University of London, 2015, s. 7 [cit. 2017-08-11]. Dostupné z: http:/ /www. arbitration.qmul.ac.uk/research/2015/ 
žádná informace o rozhodčím řízení. Jakákoli transparentnost ${ }^{6}$ by tak byla vyloučena. Současná situace je jiná. Zejména povinnost zachovat mlčenlivost není absolutní a za jejím prolomením v řadě případů stojí veřejné zájmy. Zaznívají rovněž hlasy, že existuje veřejný zájem na vyšší míře transparentnosti v mezinárodní obchodní arbitráži, zejména v podobě zveřejňování rozhodčích nálezů.

Cílem tohoto článku není podrobná analýza neveřejnosti mezinárodní obchodní arbitráže a povinnosti zachovat mlčenlivost. ${ }^{7}$ Cílem je analýza otázky, do jaké míry má a má mít transparentnost místo v mezinárodní obchodní arbitráži. Článek bude směřovat zejména k zodpovězení otázky, zda existuje veřejný zájem na systematickém zveřejňování rozhodčích nálezů. $V$ úvodu bude stručně shrnut současný stav neveřejnosti a mlčenlivosti v mezinárodní obchodní arbitráži. Následovat bude vymezení transparentnosti a jejích jednotlivých aspektů. Dále bude zhodnocena současná míra transparentnosti v mezinárodní obchodní arbitráži. Stěžejní část bude poté věnována otázce zveřejňování rozhodčích nálezů.

\section{Neveřejnost mezinárodní obchodní arbitráže a povinnost zachovat mlčenlivost - současný stav}

\subsection{Rozdíl mezi neveřejností a povinností zachovat mlčenlivost}

Mezi neveřejností rozhodčího řízení a mlčenlivostí je nutné rozlišovat a tento rozdíl je široce respektován. ${ }^{8}$ Obě představují nástroje, které kontrolují př́stup třetích osob

6 Autorka si je plně vědoma, že slovo transparentnost, které je převzaté $\mathrm{z}$ anglické odborné literatury $\mathrm{k}$ tomuto tématu, není ideální. Netransparentnost může být chápána i jako nezákonnost. To ale není tento prŕpad. Vhodným českým termínem by mohla být otevrenost. Pojem veřejnost je dle názoru autorky užší, protože je spojován zejména s fází ústního jednání. Tak je ostatně používán i v tomto článku. Autorka se rozhodla ponechat termín transparentnost s tím, že dále v článku vysvětluje, co tímto pojmem rozumí. Tento termín se navíc objevuje v obdobném významu i v související oblasti investiční arbitráže (viz např. Návrh Rozhodnutí Rady o uzavření Úmluvy Organizace spojených národů o transparentnosti $\mathrm{v}$ rozhodčím řízení mezi investorem a státem na základě smlouvy jménem Evropské unie. COM(2015) 020 final [online]. In: EUR-Lex [cit. 2017-09-10]. Dostupné z: http://eur-lex.europa.eu/legal-content/ CS/TXT/HTML/?uri=CELEX:52015PC0020 \& from=CS).

7 Řadě aspektů se autorka věnovala ve svých předchozích publikacích. Viz DRLIČKOVÁ, Klára. Legal Basis of Parties‘ Duty to Maintain Confidentiality in International Commercial Arbitration. In: DRLIČKOVÁ, Klára a Tereza KYSELOVSKÁ (eds.). COFOLA INTERNATIONAL 2016 [online]. Brno: Masarykova univerzita, s. 21-37 [cit. 2017-08-15]. Dostupné z: https://www.law.muni.cz/sborniky/cofola-international/cofola2016.pdf; DRLIČKOVÁ, Klára. Confidentiality of the Materials Used in the Course of Arbitral Proceedings. In: BĚLOHLÁVEK, Alexander a Naděžda ROZEHNALOVÁ (eds.). Czech (\& Central European) Yearbook of Arbitration. Volume VII. The Hague: Lex Lata, 2017, s. 45-66.

8 DE LY, Filip, Mark FRIEDMAN a Luca RADICATI DI BROZOLO. International Law Association International Arbitration Committee's Report and Recommendations on Confidentiality in International Commercial Arbitration. Arbitration International [online]. 2012, roč. 28, č. 3, s. 358 [cit. 2017-08-05]. Dostupné z: https://academic.oup.com/arbitration/article/28/3/355/196598/ International-Law-Association-International 
do rozhodčího řízení. ${ }^{9}$ Neveřejnost se dotýká zejména fáze ústního jednání a reguluje možnost osob, které se na rozhodčím řízení nepodílí (tedy osoby odlišné od stran, jejich právních zástupců, rozhodců, svědků apod.), aby se jednání zúčastnili. ${ }^{10} \mathrm{Na}$ druhou stranu, povinnost zachovat mlčenlivost znamená, že informace nemůže být „,vyzrazena“ třetí osobě. ${ }^{11} \mathrm{U}$ povinnosti zachovat mlčenlivost v mezinárodní obchodní arbitráži zkoumáme, zda existuje, komu náleží, jaký je její rozsah a zda existují výjimky z této povinnosti. Informaci, která je předmětem této povinnosti, lze označit jako důvěrnou. ${ }^{12}$ Důvěrnostî potom souhrnně rozumíme jak povinnost konkrétních osob zachovat mlčenlivosti, tak i předmět této povinnosti.

Neveřejnost je v mezinárodní obchodní arbitráži mezinárodně uznávána. ${ }^{13} \mathrm{O}$ jejím úplném prolomení nejsou vedeny diskuse. To ovšem neznamená, že se ústního jednání nemohou zúčastnit konkrétní třetí osoby. Jejich účast však podléhá v závislosti na konkrétní úpravě souhlasu stran či souhlasu stran a rozhodců. Je nutné rozlišovat mezi účastí konkrétních třetích osob a veřejností, tedy blíže neurčeného okruhu osob. ${ }^{14} \mathrm{~V}$ České republice je neveřejnost výslovně zakotvena v \ 19 odst. 3 zákona 216/1994 Sb., o rozhodčím řízení a o výkonu rozhodčích nálezů (dále jen „ZRŘ゙). Se souhlasem stran a rozhodců lze výjimečně připustit účast určitých třetích osob, např. další poradci stran, osoby zajišt'ující administrativně technický průběh ústního jednání, tlumočník, vedlejšî účastník. ${ }^{15}$

9 SMEUREANU, Ileana M. Confidentiality in International Commercial Arbitration. The Hague: Kluwer Law International, 2011, s. 3.

10 SMEUREANU, 2011, op. cit., s. 4.

11 MISTELIS, Loukas A. Confidentiality and Third Party Participation. UPS v. Canada and Methanex Corporation v. United States. Arbitration International [online]. 2005, roč. 21, č. 2, s. 213 [cit. 2017-08-05]. Dostupné z: https://academic.oup.com/arbitration/article/21/2/211/203973/ Confidentiality-and-Third-Party-Participation-UPS

12 Pro účely tohoto článku jako důvěrnou označujeme každou informaci, na kterou dopadá povinnost stran či rozhodců zachovat mlčenlivost.

13 YOUNG, Michael a Simon CHAPMAN. Confidentiality in International Arbitration. AS A Bulletin [online]. 2009, roč. 27, č. 1, s. 28 [cit. 2017-08-05]. Dostupné z: http://www.kluwerlawonline.com/abstract. php?area=Journals \& id=ASAB2009003; CROOKENDEN, Simon. Who Should Decide Arbitration Confidentiality Issue. Arbitration International [online]. 2009, roč. 25, č. 4, s. 603 [cit. 2017-08-05]. Dostupné z: https://academic.oup.com/arbitration/article/25/4/603/206326/Who-Should-Decide-Arbitration-Confidentiality; neveřejnost je zakotvena či respektována národními právními rády i pravidly rozhodčích institucí - přehled viz DRLIČKOVÁ, 2016, op. cit., s. 24.

14 BĚLOHLÁVEK, Alexander J. Zákon o roz̧̧odčm ř̌zení a o výkonu roz̧̧odčch nálezư. Komentár. 2. vyd. Praha: C. H. Beck, 2012, s. 699.

15 Ibidem, s. 699, 701. Běloblávek rovněž uvádí, že pokud by strany předem rezignovaly na vyloučení veřejnosti z rozhodčího řízení, je taková dohoda neplatná. 


\subsection{Mlčenlivost v mezinárodní obchodní arbitráži}

Ačkoli je mlčenlivost/důvěrnost často automaticky spojována s mezinárodní obchodní arbitráží16 či je vnímána jako její inherentní součást, ${ }^{17}$ situace není v současné době tak jednoznačná. K mlčenlivosti/důvěrnosti v mezinárodní obchodní arbitráži neexistuje jednotný přistup. Existence povinnosti zachovat mlčenlivost, její rozsah a výjimky z ní jsou podmíněny subjektem (zda se jedná o stranu či rozhodce), povahou informace, rozhodčí smlouvou, rozhodčími pravidly, právem rozhodným pro rozhodčí smlouvu a lex arbitri.

\subsubsection{Existence povinnosti stran a rozhodcu a jejich rozsah}

Nejsložitější je situace $\mathrm{v}$ př́ípadě povinnosti stran rozhodčího řízení zachovat mlčenlivost. $\mathrm{Na}$ tuto povinnost se nelze v mezinárodní obchodní arbitráži obecně spoléhat. Mezi jednotlivými právními rády existují rozdíly, i pokud jde o samotnou existenci této povinnosti. ${ }^{18}$ Nesporným základem této povinnosti je pouze ujednání stran, př́padně volba rozhodčí instituce, jejíž pravidla tuto povinnost zakotvují. ${ }^{19}$ Chybí-li toto ujednání, bude záležet na přístupu jednotlivých jurisdikcí. Národní úpravy rozhodčího řízení tuto povinnost zakotvují pouze zrrídka. ${ }^{20}$ Pouze menšina právních řádů ji pak vnímá jako implicitní podmínku rozhodčí smlouvy. ${ }^{21}$ Český ZRŘ povinnost stran zachovat mlčenlivost nezakotvuje. $\mathrm{V}$ českém prostředí mají strany tuto povinnost, vyplývá-li z jejich vzájemného ujednání. 22

Povinnost rozhodců je méně problematická než povinnost stran, aspoň pokud jde o její existenci. Je obecně prujímáno, že rozhodce má povinnost zachovávat mlčenlivost. ${ }^{23}$

16 FORTIER, Yves L. The Occasionally Unwarranted Assumption of Confidentiality. Arbitration International [online]. 1999, roč. 15, č. 2, s. 131 [cit. 2017-08-05]. Dostupné z: https://academic.oup.com/ arbitration/article/15/2/131/205881/The-Occasionally-Unwarranted-Assumption-of

17 LAZAREFF, Serge. Confidentiality and Arbitration: Theoretical and Philosophical Reflections. Special Supplement of the ICC International Court of Arbitration Bulletin 2009: Confidentiality in Arbitration: Commentaries on Rules, Statutes, Case Law and Practice [online]. 2009 [cit. 2017-08-07]. Dostupné z: http:/ /library.iccwbo. org/dr.htm

18 Otázce právního základu povinnosti stran se autorka věnovala v příspěvku DRLIČKOVÁ, 2016, op. cit.

$19 \mathrm{~K}$ přehledu institucí, jejichž pravidla povinnost stran zakotvují, viz např. DE LY, FRIEDMAN, RADICATI DI BROZOLO, 2012, op. cit., s. 393-396; Drličková, 2016, op. cit., s. 29-30.

20 Výslovně např. Nový Zéland, Austrálie, Španělsko či Skotsko. K přehledu úpravy jednotlivých zemí viz např. DE LY, FRIEDMAN, RADICATI DI BROZOLO, 2012, op. cit., s. 385-393; DRLIČKOVÁ, 2016, op. cit., s. 29-30.

21 Tento př́istup je zastáván zejména v Anglii, kde byl vytvořen judikaturou. Přehled klíčových rozhodnutí viz DRLIČKOVÁ, 2016, op. cit., s. 25-26.

22 BĚLOHLÁVEK, 2012, op. cit., s. 698.

23 LEW, Julian D. M., Loukas A. MISTELIS a Stefan M. KRÖLL. Comparative International Commercial Arbitration. The Hague: Kluwer Law International, 2003, s. 283; SMEUREANU, 2011, op. cit., s. 142; BORN, Gary B. International Commercial Arbitration. Volume II. 2nd ed. Alphen aan den Rijn: Kluwer Law International, 2014, s. 2004; DE LY, FRIEDMAN, RADICATI DI BROZOLO, 2012, op. cit., s. 373. 
Povinnost mlčenlivosti rozhodců vyplývá již ze samotné povahy jejich funkce rozhodovat spory. Bylo by neslučitelné s mandátem rozhodce, aby rozhodce vyzradil informace o rozhodčím řízení třetím osobám. ${ }^{24}$ Povinnost mlčenlivosti je klíčovou součástí role rozhodce. ${ }^{25} \mathrm{~V}$ České republice je povinnost rozhodců výslovně zakotvena v $\int 6$ odst. 1 ZR Ř. Pokud jde o rozsah povinnosti zachovávat mlčenlivost, bude vždy nutné brát v potaz, zda se jedná o povinnost rozhodce či stran a rovněž to, z jakého zdroje tato povinnost vyplývá (např. národní právo, ${ }^{26}$ ujednání stran o mlčenlivosti, rozhodčí pravidla ${ }^{27}$ ). Existenci povinnosti lze zkoumat ve vztahu ke třem okruhům „informací: samotná existence rozhodčího řízení včetně základních informací o sporu a o řízení; materiály, dokumenty či informace vytvořené nebo použité v průběhu rozhodčího řízení; ${ }^{28}$ rozhodčí nález.

\subsubsection{Vyjjimky z.povinnosti stran a rozhodci zachovat mlčenlivost}

Povinnost rozhodců a zejména stran není absolutní. Dochází k situacím, kdy je důvěrnost informace prolomena $z$ legitimních důvodů a strana či rozhodce tak neponesou odpovědnost za porušení povinnosti zachovat mlčenlivost. Rozsah a účinek výjimek

24 SMEUREANU, 2011, op. cit., s. 142; BORN, 2014, op. cit., s. 2004.

25 BORN, 2014, op. cit., s. 2004; DE LY, FRIEDMAN, RADICATI DI BROZOLO, 2012, op. cit., s. 373.

26 Viz nap̌r. \14 B ve spojení s \ 2 novozélandského zákona o rozhodčím řízení (Arbitration Act 1996, Public Act 1996 No 99, reprint 1 March 2017 [online]. New Zealand Legislation [cit. 2017-08-14]. Dostupné z http://www.legislation.govt.nz/act/public/1996/0099/latest/DLM403277.html); článek 24 odst. 2 španělského zákona o rozhodčím řízení (zákon č. 60/2003 ze dne 23. prosince 2003 o rozhodčím ř́zení [online]. Ministerio de Justicia [cit. 2017-08-13]. Dostupné z: http://www.mjusticia.gob.es/cs/ Satellite/Portal/1292426982249); Pravidlo 26 Skotských rozhodčích pravidel - Skotská rozhodčí pravidla tvoří součást skotského zákona o rozhodčím řízení a dle jeho $\int 7$ se použijí na všechna rozhodčí řízení konající se ve Skotsku (Arbitration (Scotland) Act 2010 [online]. legislation.gov.uk [cit. 2017-08-14]. Dostupné z: http://www.legislation.gov.uk/asp/2010/1/contents); \23C ve spojení s \15 australského zákona o rozhodčím řízení (International Arbitration Act 1974, Act No. 136 of 1974 [online]. Federal Register of Legislation. Australian Government [cit. 2017-08-14]. Dostupné z: https://www.legislation.gov. $\mathrm{au} /$ Details/C2011C00342).

27 Viz např. článek 22 Pravidel ACICA (Rozhodčí pravidla Australského centra pro mezinárodní obchodní arbitráž z roku 2016 [online]. Australian Centre for International Commercial Arbitration [cit. 2017-08-13]. Dostupné z: https:/ / acica.org.au/acica-rules-2016/); článek 44 Švýcarských pravidel (Švýcarská pravidla mezinárodního rozhodčího řízení z roku 2012 [online]. Swiss Chambers' Arbitration Institution [cit. 2017-0813]. Dostupné z: https://www.swissarbitration.org/Arbitration/Arbitration-Rules-and-Laws); článek 43 Pravidel DIS (Rozhodčí pravidla Německého institutu pro rozhodčí řízení (DIS) z roku 1998 [online]. DIS [cit. 2017-08-13]. Dostupné z: http://www.disarb.org/en/16/rules/overview-id0); článek 8 odst. 1 Milánských pravidel (Rozhodčí pravidla Milánské rozhodčí komory z roku 2010 [online]. Milan Chamber of Arbitration [cit. 2017-08-13]. Dostupné z: https://www.camera-arbitrale.it/en/arbitration/arbitration-rules.php?id=64); článek 38 odst. 2 Pravidel CIETAC (Rozhodčí pravidla Čínské mezinárodnî ekonomické a obchodní rozhodčí komise z roku 2015 [online]. China International Economic and Trade Arbitration Commission [cit. 2017-08-13]. Dostupné z: http://www.cietac.org/index.php?m=Page \& a=index \& id=106 \& l=en); článek 30 odst. 1 Pravidel LCIA (Rozhodčí pravidla Londýnského mezinárodního arbitrážního soudu z roku 2014 [online]. London Court of International Arbitration [cit. 2017-14-08]. Dostupné z: http://www.lcia.org/Dispute_Resolution_Services/lcia-arbitration-rules-2014.aspx).

28 Této otázce se autorka věnovala v článku DRLIČKOVÁ, 2017, op. cit. 
se bude lišit stát od státu. ${ }^{29}$ Obecně je možné vymezit pouze určité kategorie výjimek, se kterými lze v mezinárodní obchodní arbitráži počítat. Mezi ně mimo jiné patří souhlas stran rozhodčího řízení, sdělení informací profesionálním poradcům, ochrana legitimního zájmu strany rozhodčího řízení či příkaz nebo přivolení soudu. ${ }^{30}$

Nad povinností zachovat mlčenlivost mohou převážit i veřejné zájmy. Široce respektovanou výjimkou je použití informace v soudním řízení, které s rozhodčím řízením souvisí. Typicky se jedná o řízení o zrušení nálezu či řízení o uznání, prohlášení vykonatelnosti či výkonu rozhodčího nálezu. ${ }^{31} \mathrm{~V}$ těchto případech dochází k prolomení důvěrnosti především samotného nálezu. Soudní řízení je zásadně veřejné a není důvěrné. Soudy jsou státní orgány a primárně slouží veřejnému zájmu. Na veřejném soudním řízení existuje veřejný zájem; veřejné řízení včetně zveřejnění rozhodnutí je jedním z hlavních aspektů práva na spravedlivý proces. $V$ tomto případě veřejný zájem na veřejnosti soudního řízení a zejména rozhodnutí zpravidla převáží nad zájmy stran. ${ }^{32}$

Strana rozhodčího řízení či rozhodce může mít oznamovací povinnost vyplývající ze zákona, jiné úpravy či př́kazu určitého orgánu. Tato kategorie pokrývá široký soubor situací, kdy může dojít k prolomení povinnosti mlčenlivosti často z důvodu veřejného zájmu. Existence a šîre oznamovací povinnosti bude záviset na národních právních řádech dopadajících na strany i na povaze stran a jejich činnosti v určitém obchodním sektoru. Oznamovací povinnost může být vyžadována orgány veřejné moci v př́padě nezákonného jednání. ${ }^{33} \mathrm{~V}$ mezinárodní obchodní arbitráži mohou být řešeny spory, které jsou dotčeny nezákonným jednáním. V současné době jsou nejvíce diskutovány spory dotčené korupcí. ${ }^{34} \mathrm{~V}$ tomto kontextu tak typicky může dojít $\mathrm{k}$ prolomení povinnosti

29 DE LY, FRIEDMAN, RADICATI DI BROZOLO, 2012, op. cit., s. 375.

$30 \mathrm{~K}$ těmto výjimkám viz např. DE LY, FRIEDMAN, RADICATI DI BROZOLO, 2012, op. cit., s. 375-376; HWANG, Michael a Katie CHUNG. Defining Indefinable: Practical Problems of Confidentiality in Arbitration. Journal of International Arbitration [online]. 2009, roč. 26, č. 5, s. 641-642 [cit. $2017-$ 08-14]. Dostupné z: http://www.kluwerlawonline.com/abstract.php?area=Journals \& id=JOIA2009034

31 DE LY, FRIEDMAN, RADICATI DI BROZOLO, 2012, op. cit., s. 375. V ČR viz např. usnesení Krajského soudu v Brně ze dne 31. července 2012, sp. zn. 15Co 144/2012. In: ASPI. Wolters Kluwer [cit. 2017-08-16]; nález Ústavní soudu ze dne 24. června 2014, sp. zn. I.ÚS 1647/13. In: ASPI. Wolters Kluwer [cit. 2017-08-16]; nález Ústavní soudu ze dne 27. ledna 2015, sp. zn. III.ÚS 2588/13. In: ASPI. Wolters Kluwer [cit. 2017-08-16].

32 Podrobnou analýzu této otázky poskytl anglický Court of Appeal. Viz Rozhodnutí Court of Appeal, Spojené království ze dne 25. března 2004, Department of Economic Policy and Development of the City of Moscow and the Government of Moscow v. Bankers Trust Company and International Industrial Bank [online]. British and Irish Legal Information Institute [cit. 2017-08-14]. Dostupné z: http://www.bailii. org/ew/cases/EWCA/Civ/2004/314.html

33 THOMSON, Claude R. a Annie M. K. FINN. Confidentiality in Arbitration: A Valid Assumption? A Proposed Solution! Dispute Resolution Journal [online]. 2007, May/July, s. 78 [cit. 2017-08-14]. Dostupné z: http://www.fasken.com/files/Publication/568c56f5-32fd-486d-86a1-6ad2693bff04/Presentation/ PublicationAttachment/ebde4cc6-13ea-429f-9a9a-6e50018e8bca/Confidentiality_in_Arbitration.PDF

34 Např. dle \ 386 zákona č. 40/2009, trestní zákoník je trestné neoznámení trestného činu přijetí úplatku i podplácení. 
rozhodce zachovat mlčenlivost, pokud se v souvislosti s rozhodčím řízením dozvěděl o nezákonném (trestném) jednání. ${ }^{35}$

Je-li stranou mezinárodní obchodní arbitráže stát, př́padně právnická osoba veřejného práva či právnická osoba soukromého práva vlastněná či ovládána státem a strany jsou vázány povinností zachovat mlčenlivost, může se tato povinnost státu dostat do střetu s povinností podle legislativy upravující svobodný př́stup k informacím $\mathrm{v}$ daném státě. ${ }^{36}$ I taková povinnost musí být v mezinárodní obchodní arbitráži uznána jako výjimka z povinnosti mlčenlivosti. Rozsah požadovaných informací se bude lišit v závislosti na př́slušné právní úpravě. ${ }^{37} \mathrm{Je}-\mathrm{li}$ stranou společnost operující na finančním trhu, mưže oznamovací povinnost vyplývat z pravidel regulujících takový trh. ${ }^{38}$ Oznamovací povinnost může vyplývat i ze vztahu společnosti k jejím auditorům, bankám, pojišt'ovnám, investorům, členům či potencionálním smluvním partnerům. ${ }^{39}$ Rozsah oznamovací povinnosti se $\mathrm{v}$ jednotlivých př́padech liší.

V neposlední řadě může být mlčenlivost prolomena existencí legitimního zájmu veřejnosti na informacích o rozhodčím řízení. Existence tohoto zájmu může existovat $\mathrm{z}$ důvodu povahy stran či strany mezinárodního rozhodčího řízení (stranou je stát, veřejnoprávní entita či státem vlastněná společnost), povahy sporné transakce či z důvodu, že spor zahrnuje veřejné finanční prostředky. Konkrétní kontury však budou záviset na okolnostech každého případu a dané jurisdikci.

Veřejný zájem figuruje jako možné prolomení povinnosti mlčenlivosti v těch národních úpravách, které povinnost mlčenlivosti zakotvují (viz \14C písm. e) v kombinaci s \14E novozélandského zákona o rozhodčím řízení, \23G australského zákona o rozhodčím řízení či Pravidlo 26 odst. 1 písm. e) Skotských rozhodčích pravidel). Této otázce se věnovalo i slavné rozhodnutí High Court of Australia v prípadu Esso v. Plowman. ${ }^{40}$ Toto rozhodnutí v 90. letech 20. století v zásadě odstartovalo diskuse o tom, zda a za jakých

35 ZIADÉ, Nassib G. Addressing Allegations and Findings of Corruption. In: BAIZEAU, Domitille a Richard H. KREINDLER (eds.). Addressing Issues of Corruption in Commercial and Investment Arbitration. Dossiers of the ICC Institute of World Business Law [online]. 2015, roč. 13, s. 125 [cit. 2017-08-14]. Dostupné z: http://www.kluwerarbitration.com/; BORN, 2014, op. cit., s. 2005. V České republice by rozhodce musel být zproštěn mlčenlivosti postupem dle $\int 6$ odst. 2 ZRŘ.

36 V České republice zákon 106/1999 Sb., o svobodném př́stupu k informacím.

37 DE LY, FRIEDMAN. RADICATI DI BROZOLO, 2012, op. cit., s. 376; BURN, George a Alison PEARSALL. Exceptions to Confidentiality in International Arbitration. Special Supplement of the ICC International Court of Arbitration Bulletin 2009: Confidentiality in Arbitration: Commentaries on Rules, Statutes, Case Law and Practice [online]. 2009, s. 32 [cit. 2017-08-14]. Dostupné z: http://library.iccwbo.org/dr.htm

38 BURN, PEARSALL, 2009, op. cit., s. 35.

39 SMEUREANU, 2011, op. cit., s. 129.

40 Rozhodnutí High Court of Australia ze dne 7. dubna 1995, Esso Australia Resources Ltd v. Plowman [online]. Australasian Legal Information Institute [cit. 2017-08-14]. Dostupné z: http://www.austlii.edu.au/cgi-bin/sinodisp/au/cases/cth/HCA/1995/19.html?stem $=0$ \& synonyms $=0$ \& query $=$ title $(\% 221995 \% 20$ HCA $\% 2019 \% 22$ ) 
podmínek v rozhodčím řízení strany zavazuje povinnost mlčenlivosti. High Court striktně odlišil neveřejnost rozhodčího řízení a povinnost stran zachovat mlčenlivost a dospěl k závěru, že mlčenlivost není zásadním atributem rozhodčího řízení, která ukládá stranám povinnost nezveřejňovat řízení nebo dokumenty a informace poskytnuté $\mathrm{v}$ rámci a pro účely rozhodčího řízení. Taková povinnost by mohla vyplývat z výslovného ujednání stran.

Kromě toho se rozhodnutí zabývá otázkou veřejného zájmu jako výjimkou z povinnosti stran zachovat mlčenlivost. Základem případu byly dvě smlouvy o dodávce zemního plynu, kdy odběrateli byly dvě veřejnoprávní entity státu Victoria. Mezi dodavatelem a odběrateli vznikl spor ohledně zvýšení ceny plynu a v souladu se smlouvami bylo zahájeno rozhodčí řízení. Ministr Victorie pro energii a nerostné zdroje zahájil soudní řízení, ve kterém se domáhal určení, že veškeré informace získané odběrateli v průběhu rozhodčího řízení nepodléhají povinnosti zachovat mlčenlivost.

Soudce Mason dospěl k závěru, ${ }^{41}$ že třetí osoby a veřejnost mohou mít legitimní zájem vědět, co se děje v rozhodčím řízení. Vyšel z toho, že ve veřejném sektoru je potřeba otevřenost. Dle jeho názoru není důvod, proč by spotřebitelé a veřejnost Victorie neměli vědět, co se v rozhodčím řízení děje, když jeho výsledek ovlivní konečné ceny plynu účtované spotřebitelům. Z rozhodnutí je rovněž zřejmé, že veřejný zájem nedopadá pouze na informace o existenci rozhodčího řízení a dokumenty v něm vytvořené, ale i dokumenty, které byly $\mathrm{v}$ rozhodčím řízení předloženy některou ze stran. ${ }^{42}$ Toto rozhodnutí dokládá, že v určitých situacích může mít veřejnost legitimní zájem na informacích o rozhodčím řízení, který prolomí povinnost stran zachovat mlčenlivost. Tato výjimka byla však v tomto rozhodnutí koncipována př́liš extenzivně. Stejný účel by naplnil i menší zásah do důvěrnosti rozhodčího ř́izení.

\section{Transparentnost v mezinárodní obchodní arbitráži}

\subsection{Pojem transparentnosti a její současný stav}

Transparentnost $\mathrm{v}$ nejširším slova smyslu zahrnuje zveřejnění informací o rozhodčím řízení, přístup $\mathrm{k}$ nejrůznějším dokumentům pocházejícím z rozhodčího řízení, účast

41 Tento názor byl přijat většinou soudců.

42 Veřejným zájmem se zabýval např. i novozélandský soud v př́padu Television New Zealand Ltd vs. Langeley Productions Ltd. V tomto př́padě šlo o spor mezi televizním reportérem, jeho produkční společností a veřejnoprávní televizí. Spor byl řešen v dưvěrném rozhodčím řízení a rozhodci vydali nález ve prospěch produkční společnosti. Společnost požádala o výkon nálezu, zatímco televize požádala o zrušení nálezu a žádala veřejné řízení, druhá stran se však odvolávala na důvěrnost rozhodčího řízení. Soud dospěl k závěru, že povaha jedné ze stran (státem vlastněná a financovaná společnost) a předmět dotčené smlouvy (zprávy na veřejnoprávní televizi) jsou elementy, které sporu propůjčují důležitý veřejný zájem. Klíčový význam soud přiznal i tomu, že zde šlo o veřejné finance. Jinými slovy, televize je financovaná z veřejných zdrojů, veřejnost má tedy právo vědět, jak jsou její peníze utráceny (SMEUREANU, 2011, op. cit., s. 119-120). 
třetích stran na rozhodčím rrízení a přístup k ústnímu jednání. ${ }^{43}$ Takto široce je transparentnost koncipována $\mathrm{v}$ Pravidlech UNCITRAL o transparentnosti v rozhodčím řízení mezi státem a investorem na základě smlouvy. ${ }^{44}$ Ta jsou však použitelná pouze na investiční arbitráž. ${ }^{45}$ Ačkoli se v literatuře objevil názor o možné aplikaci Pravidel UNCITRAL o transparentnosti i v mezinárodní obchodní arbitráži ${ }^{46} \mathrm{~s}$ tímto názorem nesouhlasím. Takto široce koncipovaná transparentnost nepřichází v mezinárodní obchodní arbitráži v úvahu.

Výše bylo řečeno, že neveřejnost je v mezinárodní obchodní arbitráži mezinárodně uznávána, není zpochybňována a o jejím prolomení nejsou vedeny diskuse. Neveřejnost patří mezi očekávání, která strany s tímto způsobem řešení sporů spojují. Neveřejnost přispívá k procesní integritě rozhodčího rrízení. Mưže rovněž napomoci k hospodárnému a rychlému řešení sporů. ${ }^{47}$ Zároveň odlišuje rozhodčí řízení od řízení soudního. Dle názoru autorky v současné době neexistuje dostatečně silný veřejný zájem, který by nad neveřejností mezinárodní obchodní arbitráže převážil. Veřejný zájem na informacích o rozhodčím řízení lze zajistit jinak, aniž by bylo nutné poprúít jeden ze základních rysů obchodní arbitráže. V mezinárodní obchodní arbitráži tak transparentnost nelze spojovat s právem veřejnosti účastnit se rozhodčího řízení a získat plný přístup k dokumentům. ${ }^{48}$ Rovněž účast konkrétních třetích osob by měla být v mezinárodní obchodní arbitráži výjimkou a měla by být nadále podmíněna souhlasem stran a rozhodců. ${ }^{49} \mathrm{~V}$ mezinárodní obchodní arbitráži lze rovněž stěží uvažovat o systematickém zveřejňování základních informací o rozhodčím řízení tak, jak s tím např́iklad počítá článek 2 Pravidel UNCITRAL o transparentnosti. To by představovalo nepřiměřený zásah do důvěrnosti

43 CARMODY, M. Overturning the Presumption of Confidentialiaty: Should the UNCITRAL Rules on Transparency be Applied to International Commercial Arbitration? International Trade and Business Law Review [online]. 2016, roč. XIX, s. 103-104 [cit. 2017-08-15]. Dostupné z: https://home.heinonline.org/

44 UNCITRAL Rules on Transparency in Treaty-based Investor-State Arbitration [online]. UNCITRAL [cit. 2017-08-16]. Dostupné z: http://www.uncitral.org/pdf/english/texts/arbitration/rules-on-transparency/Rules-on-Transparency-E.pdf

45 Článek 1 Pravidel UNCITRAL o transparentnosti.

46 Viz CARMODY, 2016, op. cit., s. 177.

47 DIMITROV, Delyan a Laurence SHORE. The Public Interest in Private Dispute Resolution. In: ZEILER, Gerold, Irene WELSER a kol. (eds.). Austrian Yearbook on International Commercial Arbitration [online]. 2009, s. 173 [cit. 13. 8. 2017]. Dostupné z: http://www.kluwerarbitration.com/

48 ROGERS, Catherine A. Transparency in International Commercial Arbitration. Kansas Law Review [online]. 2006, roč. 54, s. 1305 [cit. 2017-08-16]. Dostupné z: https://home.heinonline.org/

49 Rovněž v odborné literatuře nejsou v tomto ohledu vedeny diskuse. Literatura věnující se neveřejnosti a důvěrnosti hovoři pouze o možných výjimkách z povinnosti zachovat mlčenlivost (viz zdroje citované výše $\mathrm{v}$ tomto článku). Literatura, která se specificky věnuje transparentnosti, se v zásadě omezuje na otázku zveřejňování rozhodčích nálezů (viz např. CARMODY, 2016, op. cit.; ROGERS, 2006, op. cit.; ZLATANSKA, Elina. To Publish, or Not To Publish Arbitral Awards: That is the Question... Arbitration [online]. 2015, roč. 81, č. 1 [cit. 2017-08-16]. Dostupné z: https://papers.ssrn.com/sol3/ papers.cfm?abstract_id=2558743; MALATESTA, Alberto a Rinaldo SALI (eds.). The Rise of Transparency in International Arbitration. New York: JurisNet, 2013. 
ř́zení. Sdělení těchto informací tak přichází v úvahu pouze v rámci výjimek z mlčenlivosti uvedených výše.

$\mathrm{V}$ posledních letech jsme svědky trendu směrem k transparentnosti v mezinárodní obchodní arbitráži. Tu lze spatřovat v několika aspektech. Mezinárodní obchodní arbitráž v žádném př́padě není zcela uzavřený a „tajný“ způsob řešení sporů, o jehož průběhu není možné získat žádné informace. To platí jak obecně, tak pro konkrétní případy.

Pravidla, kterými se rozhodčí řízení řídí, jsou dostupná a předvídatelná pro zainteresované strany. ${ }^{50}$ Nejedná se pouze o pravidla rozhodčích institucí, ale i další v praxi využívaná pravidla. ${ }^{51}$ Stále častěji dochází ke zveřejňování nálezư ${ }^{52}$ i dalších rozhodnutí rozhodčích institucí. ${ }^{53}$ Velkou roli v tomto trendu hrají právě samotné rozhodčí instituce. Tento trend vzešel ,zevnitř̌“. Nárůst sporů v oblasti mezinárodního obchodu navýšil počet a spektrum účastníků mezinárodní obchodní arbitráže. To vedlo nejen k větší soutěži mezi rozhodčími institucemi, rozhodci a stranami, ale i ke snahám o zlepšení celého systému. ${ }^{54}$

K nárůstu transparentnosti vede i dobrovolné či nedobrovolné sdělování či zveřejňování informací o rozhodčím řízení uživatelům rozhodčího řízení i obecné veřejnosti. Důvodem může být některá ze situací uvedených výše. Ačkoli jejich primárním účelem obvykle není transparentnost v mezinárodní obchodní arbitráži, ve svém souhrnu k ní přispívají. ${ }^{55} \mathrm{~K}$ transparentnosti bezpochyby přispívá i zveřejňování soudních rozhodnutí, která se rozhodčího řízení týkají (např. rozhodnutí o zrušení nálezů, rozhodnutí o uznání/ vykonatelnosti nálezư ${ }^{56}$ ). V neposlední řádě k vyšší transparentnosti připívá i obrovské množství odborné literatury, sociologických a empirických výzkumů a studií, které v této oblasti existují a stále prribývají. ${ }^{57}$

50 ROGERS, 2006, op. cit., s. 1313; CARMODY, 2016, op. cit., s. 168.

51 Viz např. soubory pravidel vytvořené International Bar Association. IBA Guides, Rules and Other Free Materials [online]. International Bar Association [cit. 2017-08-16]. Dostupné z: https://www.ibanet.org/ Publications/publications_IBA_guides_and_free_materials.aspx

52 ROGERS, 2006, op. cit., s. 1319; CARMODY, 2016, op. cit., s. 168.

53 CARMODY, 2016, op. cit., s. 168.

54 ROGERS, 2006, op. cit., s. 1313.

55 Ibidem, s. 1313.

56 Obrovské množství rozhodnutí národních soudů týkajících se uznání a výkonu rozhodčích nálezů dle Newyorské úmluvy je obsaženo v placené databázi KluwerArbitration [online]. Wolters Kluwer [cit. 201608-16]. Dostupné z: http://www.kluwerarbitration.com/. Řada rozhodnutí je však v současné době volně dostupná na 1958 New York Convention Guide [online]. UNCITRAL, Shearman \& Sterling LLP, Columbia Law School [cit. 2017-08-16]. Dostupné z: http://newyorkconvention1958.org/?opac_view=-1

57 ROGERS, 2006, op. cit., s. 1320; CARMODY, 2016, op. cit., s. 168. 


\subsection{Zveřejňování rozhodčích nálezů}

Lze však uvažovat o něčem víc? V souvislosti s vyšší mírou transparentnosti v mezinárodní obchodní arbitráži je nejčastěji skloňována otázka systematického zveřejňování rozhodčích nálezů. Ačkoli k němu již v určité míře dochází, objem zveřejněných nálezů není reprezentativní. ${ }^{58}$ Praxe rozhodčích institucí se liší. Některé nezveřejňují nic, jiné zveřejňují v poměrně v široké míre. Některé zveřejňují pouze abstrakty nálezů. Některé instituce zveřejňují volně na internetu, jiné pouze prostřednictvím placených databází. Ne všechny instituce zveřejnění nálezů upravují ve svých pravidlech, liší se i přístup k souhlasu stran..$^{5}$

Výše jsme uvedli, že veřejný zájem může stát za prolomením mlčenlivosti v konkrétních případech, kdy se do „veřejné sféry“ dostanou informace o rozhodčím řízení, některé dokumenty či právě rozhodčí nález. Mưžeme ale hovořit o veřejném zájmu na systematickém zveřejňování rozhodčích nálezů? Existují zde důvody, proč by zájem na zveřejnění nálezů měl převážit nad zájmem stran zachovat důvěrnost rozhodčího rúzení a rozhodčího nálezu? V následující pasáži se pokusím shrnout argumenty pro i proti, tyto zhodnotit a uvést, zda existuje veřejný zájem na systematické publikaci rozhodčích nálezů.

\subsubsection{Argumenty pro zuerejñováni rozhodǔch nálezư}

Veřejnost má zájem na zveřejnění rozhodčích nálezů. ${ }^{60}$ Veřejnost je důležitým hráčem v mezinárodním rozhodčím řízení. Tato premisa je primárně spojována s mezinárodní investiční arbitráží. Nicméně i mezinárodní obchodní arbitráž může mít vliv na otázky veřejného zájmu či otázky, o kterých by měla být veřejnost informována. Stranou mezinárodní obchodní arbitráže může být stát, jiná veřejnoprávní entita či společnost vlastněná či ovládána státem. I spor řešený v obchodní arbitráži se může dotýkat veřejných finančních prostř̌edků. ${ }^{61} \mathrm{~V}$ mezinárodní obchodní arbitráži jsou řešeny spory, které

58 MOURRE, Alexis. Arbitral Jurisprudence in International Commercial Arbitration: The Case for Systematic Publication of Arbitral Awards in 10 Questions [online]. Kluwer Arbitration Blog, May-28-2009, otázka 6 [cit. 2017-08-16]. Dostupné z: http://kluwerarbitrationblog.com/2009/05/28/arbitral-jurisprudence-in-international-commercial-arbitration-the-case-for-a-systematic-publication-of-arbitral-awards-in-10-questions/

59 Zajímavý prehled viz Publication of International Arbitration Awards and Decisions [online]. Report by the Committee on International Commercial Disputes, New York City Bar, 2014 [cit. 2017-08-16]. Dostupné z: http://www2.nycbar.org/pdf/report/uploads/20072645-PublicationofInternationalArbitrationAwardsandDecisions.pdf

60 HWANG, CHUNG, 2009, op. cit., s. 617.

61 CREMADÉS, Bernardo. M. a Rodrigo CORTÉS. The Principle of Confidentiality in Arbitration: A Necessary Crisis. Journal of Arbitration Studies [online]. 2013, roč. 23, č. 3, s. 31 [cit. 2017-0816]. Dostupné z: https://home.heinonline.org/; TWEEDDALE, Andrew. Confidentiality in Arbitration and the Public Interest Exception. Arbitration International [online]. 2005, roč. 21, č. 1, s. 62 [cit. 2017-08-16]. Dostupné z: https://academic.oup.com/arbitration/article/21/1/59/201202/ Confidentiality-in-Arbitration-and-the-Public 
se dotýkají i veřejných zájmů, nap̌r. soutěžní spory či spory dotčené korupcí. V mezinárodní obchodní arbitráži mohou vyjít najevo nelegální či neetické praktiky společností, jako je využívání dětské práce, poškozování životního prostředí či porušování lidských práv, ${ }^{62}$ o kterých má veřejnost právo vědět. I čistě soukromoprávní spor mưže mít výrazný vliv na širší skupiny osob, např. akcionáře či spotřebitele. ${ }^{63}$

Zveřejňování rozhodčích nálezů by mohlo vést k větší konzistentnosti rozhodování. ${ }^{64}$ Bylo by tak zajištěno obdobné řešení srovnatelných faktických a právních otázek. Konzistentnost rozhodování by přispěla $\mathrm{k}$ jednotné aplikaci pravidel, čímž by napomohla i lepšímu pochopení celého rozhodčího řízení. ${ }^{65}$ Relevance předchozích nálezů bude samozrejmě záviset na právních pravidlech dopadajících na jednotlivý prípad. Je potřeba rozlišovat mezi procesními a hmotněprávními otázkami. Ačkoli rozhodci mohou aplikovat různá procesní pravidla, existuje celá řada otázek, které jsou dnes řešeny stejně či obdobně. Tady je pak možné spatřovat prostor pro roli předchozích nálezů. Pokud jde o hmotněprávní otázky, klíčovou oblastí budou zřejmě nestátní pravidla a jejich aplikace. Přechozí nálezy však mohou být důležitým zdrojem při aplikaci unifikovaných hmotněprávních norem ${ }^{66}$ i národního práva. ${ }^{67}$

Zveřejňování nálezů by mohlo vést $\mathrm{k}$ vyšší míře jistoty a předvídatelnosti. ${ }^{68} \mathrm{I} v$ mezinárodní obchodní arbitráži strany ocení předvídatelnost výsledků. Strany se budou moci lépe rozhodnout, zda dává smysl arbitráž vưbec zahájit. To by mohlo snížit počet neodůvodněných žalob. Strany se budou moci poučit z chyb druhých, což může posílit přátelské způsoby řešení sporů. Pokud už se rozhodnou řízení zahájit, přechozí nálezy jim mohou pomoci lépe naplánovat a připravit řízení. ${ }^{69}$

Konzistentnější a předvídatelnější soubor nálezů povede k posílení integrity a legitimity rozhodčího řízení. ${ }^{70}$ Je-li práce rozhodců „viditelnějšíc, legitimita systému je posílena. Budoucí uživatelé mohou lépe pochopit celý proces, což je povede k jeho využití. Stávající uživatelé budou motivováni k jeho dalšímu využívání, pokud budou přesvědčeni, že se jim dostává spravedlivého řízení, které odpovídá jejich očekávání. ${ }^{71}$

\footnotetext{
62 ROGERS, 2006, op. cit., s. 1327.

63 CARMODY, 2016, op. cit., s. 170.

64 CARMODY, 2016, op. cit., s. 171; ZLATANSKA, 2015, op. cit., s. 29.

65 ZLATANSKA, 2015, op. cit., s. 29.

66 Jako je např. Úmluva OSN o smlouvách o mezinárodní koupi zboží.

67 MOURRE, 2009, op. cit., otázka 3; viz také Publication of International Arbitration Awards and Decisions, 2014, op. cit., s. 2.

68 CARMODY, 2016, op. cit., s. 171.

69 ZLATANSKA, 2015, op. cit., s. 28.

70 CARMODY, 2016, op. cit., s. 171; BUYS, 2003, op. cit., s. 136.

71 ZLATANSKA, 2015, op. cit., s. 29.
} 
Zveřejnění nálezů může rovněž přispět ke zvýšení kvality nálezů a jejich odůvodnění. ${ }^{72}$ Veřejný dohled může rozhodcům poskytnout větší motivaci přijímat obhajitelná a přesvědčivá rozhodnutí. Může rovněž přispět ke zvýšení kvality odůvodnění, protože rozhodce bude vědět, že jeho text bude publikován, čten a př́padně kriticky hodnocen. ${ }^{73}$

Současná mezinárodní obchodní arbitráž potřebuje vysoce kvalifikované rozhodce. Zveřejňování nálezů může napomoci výchově nových rozhodců a stávajícím poskytnout informace, jak rozhodují jiní. ${ }^{74}$ Jejich zveřejnění může napomoci budování reputace rozhodce. Zveřejnění rozhodčích nálezů může omezit špatné počínání rozhodců či špatnou aplikaci práva a připustí určitou míru externího dohledu. ${ }^{75}$

Mezinárodní obchodní arbitráži je v současné době vyčítáno, že je poměrně uzavřeným klubem osob (zejména, pokud jde o komplexnější případy), které opakovaně působí jako rozhodci, právní zástupci atd. To může vést ke střetu zájmů, protože rozhodce může upřednostnit stranu, o které ví, že si ho v budoucnu znovu vybere. Dochází tak nárůstu námitek podjatosti rozhodců. ${ }^{76}$ Větší dostupnost informací může pole obchodní arbitráže otevřít dalším osobám, což by mohlo přispět k řešení naznačeného problému. Nálezy mohou rovněž plnit důležitou informační funkci tím, že poskytují informaci o potencionálních rozhodcích a o tom, jak přistupují ke svým případům. ${ }^{77}$ Strany si mohou při výběru rozhodce zhodnotit, jak rozhodce postupoval v minulých řízeních a učinit tak odůvodněný výběr rozhodce. ${ }^{78}$

Zveřejnění nálezů může u veřejnosti posílit důvěru, že proces je spravedlivý, což zvýší pravděpodobnost plnění nálezů. Zveřejnění nálezů tak může vytvořit tlak na plnění nálezů. ${ }^{79}$ Zveřejněné nálezy mohou být rovněž zdrojem pro akademiky, kteří budou mít příležitost porozumět, analyzovat, podrobit kritice a zlepšovat tento systém řešení sporů. ${ }^{80}$ $\mathrm{V}$ neposlední řadě by mohlo zveřejnění nálezů přispět $\mathrm{k}$ budování reputace rozhodčích institucí a posílit mezi nimi zdravou soutěž. ${ }^{81}$ Rada rozhodčích nálezů rovněž představuje kvalitní právní díla. Nejsou-li zveřejněny, nemohou právo obohatit. ${ }^{82}$

\footnotetext{
72 Viz také Publication of International Arbitration Awards and Decisions, 2014, op. cit., s. 2; CREMADES, CORTÉS, 2013, op. cit., s. 35.

73 CARMODY, 2016, op. cit., s. 174; ZLATANSKA, 2015, op. cit., s. 30.

74 ZLATNASKA, 2015, op. cit., s. 29.

75 Ibidem, s. 31.

76 Ibidem, s. 30.

77 CARMODY, 2016, op. cit., s. 172.

78 BUYS, 2003, op. cit., s. 137.

79 CARMODY, 2016, op. cit., s. 174.

80 CARMODY, 2016, op. cit., s. 172; BUYS, 2003, op. cit, s. 137.

81 ZLATANSKA, 2015, op. cit., s. 32.

82 CREMADES, CORTÉS, 2013, op. cit., s. 35.
} 


\subsubsection{Argumenty proti zueréejnování nálezü}

Zveřejňování rozhodčích nálezů by mohlo vést $\mathrm{k}$ narušení rozhodčího řízení. ${ }^{83}$ Důvěrnost je stále důležitým elementem rozhodčího řízení. Zejména tam, kde je důvěrnost rozhodčího řízení výsledkem výslovného ujednání stran, může její nerespektování vést $\mathrm{k}$ tomu, že arbitráž bude méně atraktivní. ${ }^{84}$ Vyšší míra transparentnosti by mohla setřít i rozdíl mezi rozhodčím a soudním řízením. Otevřený proces může vést i k neochotě stran připustit určité skutečnosti či pozice z obavy z veřejné reakce, což by mohlo vést ke snížení efektivity rozhodčího ř́izení. ${ }^{85}$ Proti zveřejnění nálezů hovoří i možnost zveřejnění citlivých či důvěrných informací, např. obchodního tajemství, know-how, výsledků výzkumu, seznamu zákazníků, práv k duševnímu vlastnictví apod. ${ }^{86}$

Zveřejnění nálezů by mohlo vést ke zvýšení nákladů ${ }^{87}$ a zpomalení řízení. ${ }^{88}$ Náklady by mohly souviset s prrípravou nálezu k zveřejnění i jejich samotným zveřejněním. Zaznívá i argument, že rozhodci by se méně soustředili na vlastní řešení sporů, ale věnovali by větší pozornost rozvoji práva a demonstraci svých schopností, aby si zajistili budoucí př́pady. ${ }^{89}$

Oponenti rovněž uvádějí, že v mezinárodní obchodní arbitráži nevyvstává potřeba konzistentního a předvídatelného souboru rozhodnutí, protože se dotýká jednorázových smluv. ${ }^{90}$ Navíc, rozhodci většinou aplikují národní právo, které je již dostatečně rozvinuté. Většina nálezů také nebude mít hodnotu pro další případy s ohledem na specifické okolnosti. Není tak možné z nich vyvozovat obecnější závěry. ${ }^{11}$ Proti zveřejňování nálezů zaznívá i argument, že strany by nemohly skrýt tvrzení, která je poškozují. To samozřejmě nebude na škodu, pokud jsou tvrzení pravdivá. ${ }^{92}$

\subsubsection{Zhodnocení}

Systematické zveřejňování rozhodčích nálezů by mohlo přinést řadu výhod. Tyto výhody se v žádném př́padě neomezují pouze na strany konkrétního rozhodčího řízení, ale měly by daleko širší přínos. Zveřejňování rozhodčích nálezů je ve veřejném zájmu. $V$ celé

\footnotetext{
83 ZLATANSKA, 2015, op. cit., s. 32.

84 BUYS, 2003, op. cit., s. 138.

85 BUYS, 2003, op. cit., s. 138; ZLATANSKA, 2015, op. cit., s. 32.

86 BUYS, 2003, op. cit., s. 138; ZLATANSKA, 2015, op. cit., s. 32.

87 Publication of International Arbitration Awards and Decisions, 2014, op. cit., s. 3; BUYS, 2003, op. cit., s. 137; ZLATANSKA, 2015, op. cit., s. 33.

88 ZLATANSKA, 2015, op. cit., s. 33.

89 CARMODY, 2016, op. cit., s. 174.

90 CARMODY, 2016, op. cit., s. 173.

91 DIMITROV, SHORE, 2009, op. cit., s. 171.

92 BUYS, 2003, op. cit., s. 137.
} 
řadě př́padů bude mít veřejnost zájem znát a měla by mít právo znát obsah rozhodčích nálezů. Vyšší míra transparentnosti v důsledku publikace rozhodčích nálezů by prúspěla k rozvoji konzistentní rozhodovací praxe, posílení předvídatelnosti, legitimity a kvality rozhodčího řízení.

Klíčovým argumentem, který zaznívá proti publikaci nálezů, je důvěrnost rozhodčího řízení, resp. rozhodčího nálezu. K té však v současné době neexistuje jednotný přístup. $\mathrm{V}$ př́padě, kdy si strany neujednají povinnost mlčenlivosti ohledně nálezu, nebo tato nebude vyplývat z použitelných rozhodčích pravidel, je sporné, zda bude vůbec existovat. Mlčenlivost stran tak publikaci nálezů bez dalšího nebrání. Pokud však existuje, není možné ji ignorovat. Odrazí se v nastavení hranice mezi důvěrností rozhodčího nálezu a jeho zveřejněním. Při nastavení pravidel pro zveřejňování rozhodčích nálezů je nutné vyvažovat veřejný zájem na vyšší míre transparentnosti a zájem stran na zachování důvěrnosti nálezu.

Nepřijatelné jsou obě krajní pozice. Na straně jedné myšlenka, že rozhodčí nálezy budou zveřejňovány bez úprav v celém rozsahu. Na straně druhé pak pozice, že jakékoli zveřejnění nálezu bez souhlasu stran má na ně automaticky negativní dopad. ${ }^{93}$ Je tedy nutné najít „zlatou“ střední cestu. Nálezy by měly být zveřejňovány až nějakou dobu poté, co byly vydány. Měly by z nich být odstraněny určité informace - důvěrné či citlivé informace, jména stran, právních zástupců atd. Naopak, jména rozhodců by zveřejněna být měla. Mohla by přispět k lepšímu pochopení obsahu nálezu. ${ }^{94}$ Jejich zveřejnění by mohlo přinést řadu výhod, které byly uvedeny výše.

Jako inspirace může sloužit iniciativa Milánské arbitrážní komory, která vydala Pokyny pro anonymní zveřejnění rozhodčích nálezự ${ }^{95}$ dopadající na nálezy vydané dle jejích pravidel. Nálezy jsou zveřejněny, ledaže kterákoli ze stran se zveřejněním výslovně nesouhlasí. Pokyny potom podrobně vymezují, které informace z rozhodčího nálezu budou zveřejněny a které budou vypuštěny, resp. jak mají být upraveny.

Zajistit systematické zveřejňování nálezů v praxi je velmi obtížné. Důležitou roli by samozřejmě mohly hrát rozhodčí instituce. Bylo by však nutné, aby jejich pravidla alespoň obsahovala výslovná ustanovení o zveřejnění nálezů a př́padně i vzorové doložky týkající se důvěrnosti, které by na zveřejnění nálezu reagovaly. ${ }^{96} \mathrm{~V}$ tomto př́padě by ale zcela stranou zůstaly nálezy vydané v řízení ad hoc. Objevil se i návrh vytvoření mezinárodní instituce, která by zodpovídala za zveřejňování nálezů. K jejímu vytvoření by bylo třeba

93 ZLATANSKA, 2015, op. cit., s. 34.

94 MOURRE, 2009, op. cit., otázky 7 a 10.

95 Guidelines for the Anonymous Publication of Arbitral Awards [online]. Milan Chamber of Arbitration [cit. 2017-08-16]. Dostupné z: https://www.camera-arbitrale.it/Documenti/guidelines-anonymous-publication-arbitral-awards.pdf

96 ZLATANSKA, 2015, op. cit., s. 36. 
přijetí mezinárodní smlouvy a její zřízení by vyvolalo řadu praktických problémů. ${ }^{97}$ Tato možnost je v současné době nereálná. Pravděpodobnější variantou by pak bylo vytvoření online databáze a jednotných pravidel pro zveřejnění nálezů, obojí např. v gesci UNCITRALu. ${ }^{98}$ Problémem by samozřejmě bylo zajistit, aby zde alespoň velká část nálezů byla zveřejněna. ${ }^{99}$

I kdyby byla vytvořena pravidla o zveřejnění rozhodčích nálezo̊, jejich aplikace by v mezinárodní obchodní arbitráži nemohla být povinná. Stranám konkrétního řízení by musela být zachována možnost jejich aplikaci vyloučit. ${ }^{100}$ Tak by bylo možné dosáhnout vyšší míry transparentnosti, ale zároveň nepotlačit zájmy stran.

\section{Závěr}

Transparentnost $\mathrm{v}$ nejširším slova smyslu zahrnuje zveřejnění informací o rozhodčím řízení, přístup $\mathrm{k}$ nejrůznějším dokumentům pocházejícím z rozhodčího řízení, účast třetích stran na rozhodčím řízení a prístup k ústnímu jednání. Takto široce koncipovaná transparentnost je v mezinárodní obchodní arbitráži nereálná a byla by i kontraproduktivní, protože by popírala podstatu mezinárodní obchodní arbitráže i očekávání stran. $\mathrm{V}$ žádném případě tak nelze diskutovat o úplném prolomení neveřejnosti, širší účasti třetích osob či systematickém zveřejňování informací o rozhodčím řízení a různých dokumentů vytvořených či předložených v rozhodčím řízení. Domnívám se, že na takto koncipované transparentnosti neexistuje žádný veřejný zájem.

Přesto jsme svědky trendu směrem k transparentnosti v mezinárodní obchodní arbitráži. Stále častěji dochází ke zveřejňování nálezů i dalších rozhodnutí rozhodčích institucí. K nárůstu transparentnosti vede i dobrovolné či nedobrovolné sdělování či zveřejňování informací o rozhodčím řízení uživatelům rozhodčího řízení i obecné veřejnosti. $K$ transparentnosti bezpochyby přispívá i publikace soudních rozhodnutí, která se rozhodčího řízení týkají. $\mathrm{V}$ neposlední řádě k vyšší transparentnosti připívá i obrovské množství odborné literatury, sociologických a empirických výzkumů a studií.

V souvislosti s vyšší mírou transparentnosti v mezinárodní obchodní arbitráži je nejčastěji skloňována otázka zveřejňování rozhodčích nálezů. Ačkoli k ní již v určité míre dochází, objem zveřejněných nálezů není reprezentativní a praxe rozhodčích institucí se liší. Na základě zvážení argumentů pro i proti autorka dospěla k závěru, že na zveřejňování rozhodčích nálezů existuje veřejný zájem. V celé řadě př́ípadů může mít veřejnost zájem znát obsah rozhodčích nálezů. Vyšší míra transparentnosti v mezinárodní

97 ZLATANSKA, 2015, op. cit., s. 35.

98 MOURRE, 2013, op. cit., s. 66.

99 ZLATANSKA, 2015, op. cit., s. 36.

100 Ideální by byl systém tzv. opt out, kdy by se pravidla aplikovala, ledaže by strany jejich aplikaci výslovně vyloučily. 
obchodní arbitráži v důsledku zveřejňování rozhodčích nálezů by přispěla k rozvoji konzistentní rozhodovací praxe, posílení předvídatelnosti, legitimity a kvality rozhodčího řízení. Navíc, důvěrnost nálezu, resp. povinnost stran zachovat o něm mlčenlivost zveřejnění nálezu nutně nebrání. Nelze ji však ignorovat. Odrazí se v nastavení hranice mezi důvěrností nálezu a jeho zveřejněním. Při nastavení pravidel pro zveřejňování rozhodčích nálezů je nutné vyvažovat veřejný zájem na zveřejnění nálezů a zájem stran na zachování jejich důvěrnosti. 